\title{
Seabed litter distribution in the high seas of the Flemish Pass area (NW Atlantic)
}

\author{
Ana García-Alegre, Esther Román-Marcote, Jesús Gago, Gonzalo González-Nuevo, \\ Mar Sacau, Pablo Durán Muñoz \\ Centro Oceanográfico de Vigo, Instituto Español de Oceanografía, Subida a Radio Faro, 50-52, 36390 Vigo, Spain \\ (AG-A) (Corresponding author) E-mail: ana.garciaalegre@ieo.es. ORCID iD: https://orcid.org/0000-0003-1541-4938 \\ (ER-M) E-mail: esther.roman@ieo.es. ORCID iD: https://orcid.org/0000-0003-2524-4346 \\ (JG) E-mail: jesus.gago@ @ieo.es. ORCID iD: https://orcid.org/0000-0003-0188-9844 \\ (GG-N) E-mail: gonzalo.gonzaleznuevo@ieo.es. ORCID iD: https://orcid.org/0000-0002-7578-0756 \\ (MS) E-mail: mar.sacau@ieo.es. ORCID iD: https://orcid.org/0000-0002-6529-3110 \\ (PDM) E-mail: pablo.duran@ieo.es. ORCID iD: https://orcid.org/0000-0002-9618-4224
}

\begin{abstract}
Summary: Seabed litter of the Flemish Pass area (NW Atlantic Ocean) was analysed and described using data from the EU-Spain groundfish survey (2006-2017 period). This study presents baseline information on seabed litter in this area. The Flemish Pass is located in areas beyond national jurisdiction within the Northwest Atlantic Fisheries Organization Regulatory Area Division 3L. A total of 1169 valid bottom trawl hauls were analysed (104-1478 m depth). Litter was found in 8.3\% of the hauls, with mean densities of $1.4 \pm 0.2$ items km${ }^{-2}$ and $10.6 \pm 5.2 \mathrm{~kg} \mathrm{~km}^{-2}$. An increasing pattern with depth was found, the highest densities of seabed litter being identified in the deepest areas located in the Flemish Pass channel and down the northeastern flank of the Grand Bank. Fishing was found to be the main source of marine litter, and $61.9 \%$ of the hauls with litter presence showed litter included in the fisheries-related litter category. Whereas in most cases the litter was composed of small fragments of rope, in other cases it was composed of entire fishing gears such as traps. Plastics, metal and other anthropogenic litter were the next most abundant categories, accounting for $18.6 \%, 16.5 \%$ and $12.4 \%$ of the total, respectively.
\end{abstract}

Keywords: marine litter; seabed litter; fishing; Flemish Pass; northwest Atlantic.

Distribución de la basura en los fondos de alta mar en el área de Flemish Pass (Atlántico Noroccidental)

Resumen: La basura en los fondos marinos del área de Flemish Pass (Océano Atlántico Noroeste) ha sido analizada y descrita utilizando datos de las campañas demersales de EU-España (período 2006-2017). Este estudio presenta información de referencia sobre la basura en los fondos marinos de esta área. Flemish Pass está localizado en áreas más allá de las jurisdicciones nacionales dentro del Área Reguladora de la Organización para las Pesquerías del Atlántico Noroccidental División 3L. Se han analizado un total de 1169 lances de arrastre de fondo válidos (104-1478 m de profundidad). Se ha encontrado basura en el $8.3 \%$ de los lances con densidades medias de $1.4 \pm 0.2$ ítems km$~^{-2}$ y $10.6 \pm 5.2 \mathrm{~kg} \mathrm{~km}^{-2}$. Se ha hallado un patrón de aumento con la profundidad, identificándose densidades mayores de basura marina en las áreas más profundas ubicadas en el canal Flemish Pass y en el flanco noreste del Gran Banco. Se ha descubierto que la pesca es la principal fuente de basura marina, el $61.9 \%$ de los lances con presencia de basura mostraron desechos incluidos en la categoría de basura relacionada con la actividad pesquera. Mientras que en la mayoría de los casos la basura estaba compuesta por pequeños fragmentos de cabo, en otros casos estaba compuesta por aparejos como nasas. Posteriormente, los plásticos, el metal y otros desechos antropogénicos fueron las categorías más abundantes, con $18.6 \%, 16.5 \%$ y $12.4 \%$, respectivamente.

Palabras clave: basura marina; basura en los fondos marinos; pesca; Flemish Pass; Atlántico Noroeste.

Citation/Como citar este artículo: García-Alegre A., Román-Marcote E., Gago J., González-Nuevo G., Sacau M., Durán Muñoz P. 2020. Seabed litter distribution in the high seas of the Flemish Pass area (NW Atlantic). Sci. Mar. 84(1): 93-101. https://doi.org/10.3989/scimar.04945.27A

Editor: R. Sardà.

Received: April 29, 2019. Accepted: January 21, 2020. Published: February 5, 2020.

Copyright: () 2020 CSIC. This is an open-access article distributed under the terms of the Creative Commons Attribution 4.0 International (CC BY 4.0) License. 


\section{INTRODUCTION}

Marine litter has been recognized as a worldwide problem (UNEP 2016) affecting the marine environment in several ways, including economic loss, degradation of habitats and impact on biota. Marine litter is distributed in all the compartments of the marine environment: coasts, waters and the seabed (Bergmann et al. 2015). Although the number of studies on marine litter on the seabed has increased considerably in recent years (see e.g. Maes et al. 2018, Galgani et al. 2015), there are still gaps in the knowledge, especially related to the high seas. Most of the literature has documented areas close to the coast (see e.g. Neves et al. 2015, Lopez-Lopez et al. 2017, García-Rivera et al. 2018), and studies on deep bottoms and locations remote from land are relatively few (see e.g. Pham et al. 2014, Vieira et al. 2015). In this pioneering study, we analyse an extensive database containing 12 years of data on seabed litter in the NW Atlantic Ocean (2006-2017) in an area beyond national jurisdiction. The database used in the present study came from groundfish surveys whose main goal was to assess fisheries resources in this region and which were not designed to study litter on the seabed. Nevertheless, seabed litter data has been annotated since 2006.

The study area hosts several human activities such as bottom fisheries for Greenland halibut and snow crab, shipping routes and offshore oil and gas exploration (ATLAS 2018). Although hydrocarbon exploration has been growing in the area in recent years, bottom fisheries are traditionally the most important activity in the area. Several studies in different regions of the world mention fisheries litter as the major source of marine litter on the seafloor: in the Australian Bight (Edyvane et al. 2004), in Korean waters (Hong et al. 2014, Jang et al. 2014) and in the Celtic Sea (Moriarty et al. 2016). Marine litter from fisheries activities has been reported on beaches (Gago et al. 2014), floating on surface waters (Cózar et al. 2014) and located on the seafloor (Galgani et al. 2015).

There are no global estimates of the amount of plastic waste generated by the fisheries sector, but it is considered that abandoned, lost or otherwise discarded fishing gears (ALDFG) are an important source of plastic waste into the marine environment (see e.g. Lusher et al. 2017). ALDFG is a major issue for the marine environment. Its presence can have a significant impact and lead to ghost fishing, stock depletion, capture of non-target species, conservation concerns and hazards to maritime traffic (Bilkovic et al. 2014). Pham et al. (2014) estimated that overall debris on the seabed of some regions of the Mediterranean Sea and northeast Atlantic was composed mainly of plastics (41\%) and ALDFG (34\%).

According to Lusher et al. (2017), ALDFG can be a result of factors such as enforcement of fisherman to abandon gears (e.g. illegal fishing), operational pressure (e.g. use of too much gear in restricted time periods) and environmental conditions (e.g. bad weather conditions), lack of/inaccessible/expensive onshore gear and waste disposal facilities (Gilman et al. 2016).
The main objectives of this work were 1) to characterize marine litter on the seabed for this region, 2) to analyse spatial and temporal distribution for the period 2006-2017, 3) to analyse indicators for describing seabed litter, 4) to determine the main litter sources, and 5) to analyse potential drivers of seabed litter distribution.

\section{MATERIALS AND METHODS}

\section{Study area}

This study was conducted in the NW Atlantic Ocean within the Northwest Atlantic Fisheries Organization (NAFO) Div 3L Regulatory Area, in ABJN (Fig. 1). The study area includes the Flemish Pass, a channel approximately $1200 \mathrm{~m}$ deep which separates the Flemish Cap offshore bank and the Grand Banks of Newfoundland, and the NE part of the Grand Banks including the "nose". The study area holds various types of valuable habitats and ecosystems, such as deep-water corals and deep-sea sponge grounds (see Murillo et al. 2011, 2012), and is characterized by the cold southward flow of the Labrador current (Colbourne and Foote 2000).

\section{Survey characteristics}

We analysed seabed litter data recorded from the EU-Spain groundfish survey (NAFO Div 3L, outside the Canadian exclusive economic zone) carried out every summer between 2006 and 2017. Surveys were conducted on board the Spanish Research Vessel Vizconde de Eza, following the same standardized procedures and using the same bottom trawl net type, "Campelen 1800" (McCallum and Walsh 1994), with a mesh size of 44 mm cod-end and trawl doors of $1400 \mathrm{~kg}$.

The survey area was stratified following the standard stratification schemes (Bishop 1994). Surveys were conducted using a stratified random design according to NAFO specifications (Doubleday 1981). The surveys cover the entire study area (24 strata between 93 and $1463 \mathrm{~m}$ ) with 100 per year (Fig. 1). The number of hauls was allocated to strata proportionally to stratum

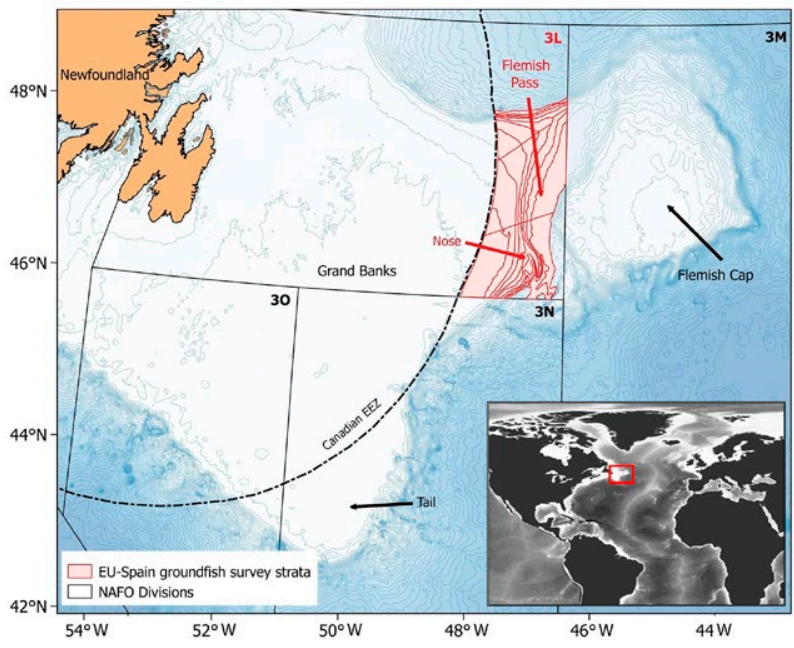

Fig. 1. - Location of the study area (in red colour), showing the divisions of the 24 strata that cover the area. 
size, with a minimum of two planned hauls per stratum, and the trawl positions were chosen at random. The effective duration of each haul was approximately 30 min and the tow speed was about 3 knots. Net and door sensors ensured that the fishing gear was properly configured at the bottom. The survey characteristics are described in detail in Román et al. (2018).

\section{Seabed litter data}

A total of 1169 trawls hauls were analysed. Litter items retained in the bottom trawl hauls were examined. At each haul, all items collected by the gear were counted, weighed, categorized and recorded on board according to seven categories: fisheries-related litter, organic debris, glass, plastics, metal, wood and other anthropogenic litter. The data were then standardized by $\mathrm{km}^{2}$ and represented using items $\mathrm{km}^{-2}$ and $\mathrm{kg} \mathrm{km}^{-2}$ for each trawl and year and by the different strata of the EU-Spain groundfish survey. These density values were calculated by the swept area, obtained by multiplying the distance trawled by the net and the estimated horizontal opening. The Pearson correlation coefficient was used to test correlation between items $\mathrm{km}^{-2}$ and $\mathrm{kg}$ $\mathrm{km}^{-2}$ at each sampling site. Additionally, the percentage of trawls with litter presence was also estimated to determine which of the three indicators best characterize the seabed litter in this area (percentage of trawls with litter presence, items $\mathrm{km}^{-2}$ or $\mathrm{kg} \mathrm{km}^{-2}$ ). A Kruskal-Wallis test was applied to test for significant differences in the items $\mathrm{km}^{-2}$ and the $\mathrm{kg} \mathrm{km}^{-2}$ by years. Additionally, pairwise Wilcox rank sum tests were used to calculate pairwise comparisons between years with corrections for multiple testing when significant differences were found in the Kruskal-Wallis test.

The fisheries-related litter category (equivalent to the ALDFG) includes items related to fisheries, and although most of them are composed of plastic or metal, they were incorporated as a separate category as was done in Pham et al. (2014) and Lopez-Lopez et al. (2017). Fishing activity is historically the most significant human activity in the area and we considered it important to take into account this type of litter category separately. We included organic debris in the study (accounting for only 1\% of the marine litter captured), following the definition of Galgani et al. (2010).

According to Veiga et al. (2016), all the marine litter found in our study area can be classified into the sea-based sources. The marine litter categories were therefore classified following the classification by indicator-items sources of OSPAR (2007a).

\section{Potential driver data}

Depth, fishing effort and bottom current speed were considered potential drivers that could affect the distribution pattern of the seabed litter in the study area.

These data were aggregated with the same spatial resolution of $0.013 \times 0.013$ decimal degrees using the 'raster' package Hijmans et al. (2016) in the R software ( $\mathrm{R}$ Core Team 2017). A generalized additive model (Hastie et al. 2001, Wood and Augustine 2002) was im- plemented using the 'mgcv' and 'dismo' packages in R 3.4.2 to test the importance of the potential drivers in the seabed litter distribution. Before using these predictors in the model, they were tested for collinearity, correlation, outliers and missing data following the procedure of Zuur et al. (2010). Default thin plate regression splines were used as the smoothing function for the predictors (Wood 2003), limiting the smoothing to 4 degrees of freedom for each spline to avoid overfitting.

Bathymetry was merged from the MARSPEC database (Sbrocco and Barber 2013) with a spatial resolution of $\sim 1 \mathrm{~km}$ and the multibeam data obtained with the EM 302 multibeam echosounder on board the Spanish R/V Miguel Oliver during the NEREIDA (Durán Muñoz et al. 2012) multidisciplinary surveys (2009-2010 period), with a resolution of $75 \mathrm{~m}$. The depth bottom current speed was extracted from the Viking 20 model (Behrens et al. 2017, Breusing et al. 2016). Fishing effort was included using vessel monitoring system data from 2008-2014 non-sedentary bottom fisheries (the target species were non-sedentary species) following the NAFO (2015) filtering procedure.

\section{RESULTS}

\section{Spatial distribution of litter}

Marine litter was found in $8.3 \%$ of the total trawls, with mean densities of $1.4 \pm 0.2$ items $\mathrm{km}^{-2}$ and $10.6 \pm 5.2$ $\mathrm{kg} \mathrm{km}^{-2}$. Table 1 presents the following data grouped by year and for the whole period: the number of valid bottom trawl hauls performed, the percentage of them with litter presence and the mean values of densities in $\mathrm{kg} \mathrm{km}^{-2}$ and items $\mathrm{km}^{-2}$ of marine litter.

The highest presence and densities of marine litter were found in the north and northeast part of the study area. Figure 2A shows the location of the hauls with absence and presence of litter in the trawl gear and the percentage of presence of litter in the hauls by sampling strata, according to the NAFO stratification scheme. Figures $2 \mathrm{~B}$ and $2 \mathrm{C}$ show the distribution of litter in terms of densities estimated in items $\mathrm{km}^{-2}$ and $\mathrm{kg} \mathrm{km}^{-2}$, respectively, by haul and by strata.

Slight variations were observed according to the indicator used: percentage of presence of litter in the

Table 1. - Mean values of marine litter densities estimated by weight $\mathrm{km}^{-2}$ and number of items $\mathrm{km}^{-2}$ per year and in total. $\mathrm{N}$ is the number of valid trawls performed and $\%$ is the percentage of valid trawls with litter presence.

\begin{tabular}{lcccc}
\hline Year & $\mathrm{N}$ & $\%$ & $\mathrm{Kg} \mathrm{km}^{-2}$ & $\mathrm{Item} \mathrm{km}^{-2}$ \\
\hline 2006 & 100 & 19.0 & $3.8 \pm 2.1$ & $4.1 \pm 1$ \\
2007 & 94 & 17.0 & $97.6 \pm 63.5$ & $3.1 \pm 0.9$ \\
2008 & 100 & 7.0 & $1.9 \pm 1.1$ & $1.4 \pm 0.6$ \\
2009 & 98 & 6.1 & $0.4 \pm 0.2$ & $0.8 \pm 0.3$ \\
2010 & 97 & 4.1 & $0.2 \pm 0.1$ & $0.8 \pm 0.4$ \\
2011 & 89 & 3.4 & $0.9 \pm 0.8$ & $0.6 \pm 0.3$ \\
2012 & 98 & 8.2 & $8.1 \pm 5.9$ & $1.3 \pm 0.5$ \\
2013 & 100 & 4.0 & $3.5 \pm 2.4$ & $0.9 \pm 0.5$ \\
2014 & 99 & 5.1 & $6.7 \pm 4.2$ & $0.9 \pm 0.5$ \\
2015 & 97 & 5.2 & $1.1 \pm 0.6$ & $0.6 \pm 0.3$ \\
2016 & 98 & 12.2 & $4.5 \pm 2.2$ & $1.5 \pm 0.4$ \\
2017 & 99 & 8.1 & $1.9 \pm 1.1$ & $1.2 \pm 0.4$ \\
$2006-2017$ & 1169 & 8.3 & $10.6 \pm 5.2$ & $1.4 \pm 0.4$ \\
\hline
\end{tabular}



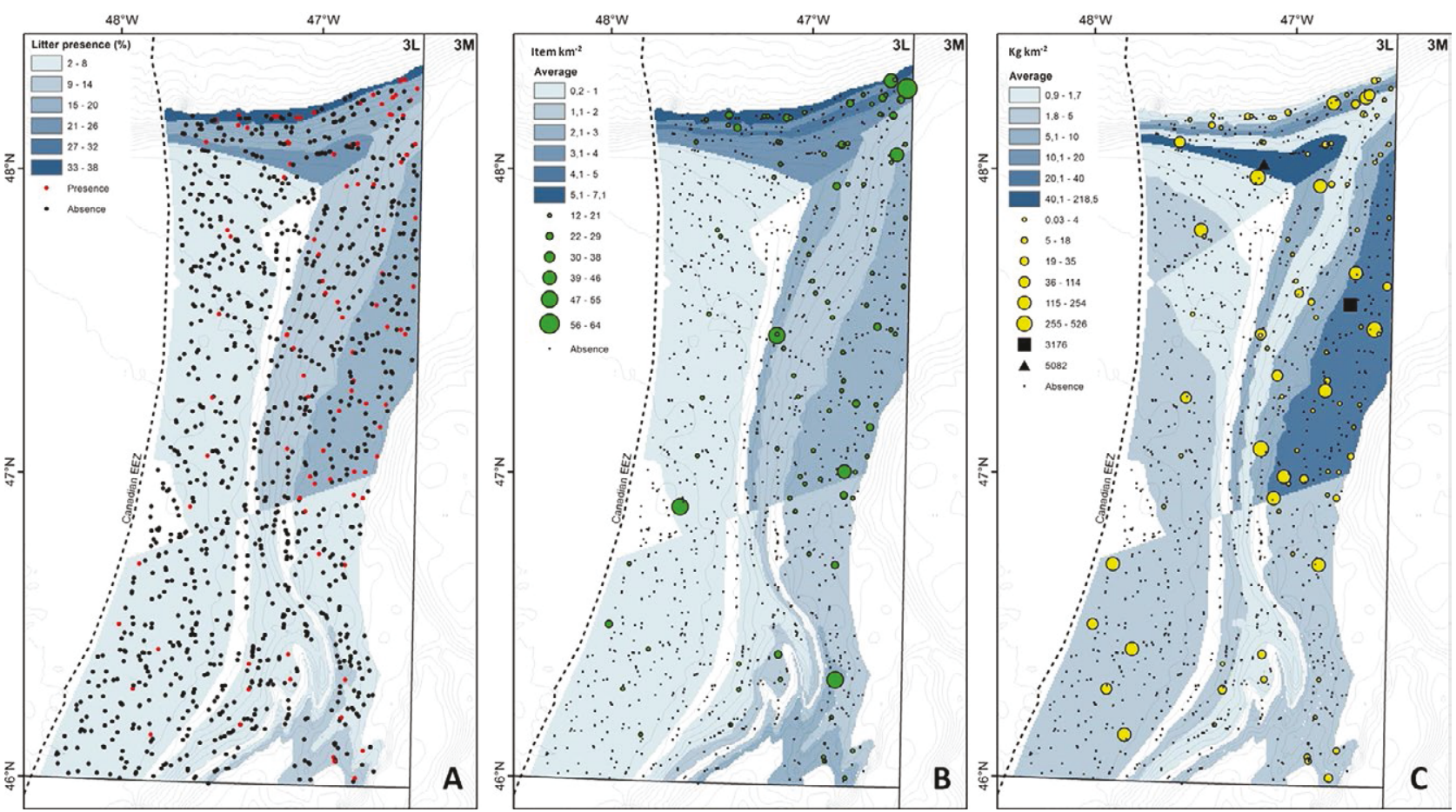

Fig. 2. - Distribution of seabed litter by haul and by strata of percentage of trawls with litter presence (A), items km-2 (B) and kg km-2 (C), where the black triangle and square represent items with a weight of 400 and $250 \mathrm{~kg}$, respectively.

hauls by strata and items $\mathrm{km}^{-2}$ showed a similar pattern, while $\mathrm{kg} \mathrm{km}^{2}$ showed differences in some strata. Indeed, there was no correlation between items $\mathrm{km}^{-2}$ and $\mathrm{kg} \mathrm{km}^{-2}$ (Pearson coefficient $\left.=0.065\right)$, corroborating the singular measure of each indicator.

Taking into account the time series data, higher densities of seabed litter were found in the years 2006 and 2007, and the values declined in the following years (Table 1). Kruskal-Wallis tests confirmed significant differences by year (Kruskal-Wallis $\mathrm{kg} \mathrm{km}^{-2}$ - Year=35.782, 11df, $\mathrm{P}<0.001$; Kruskal-Wallis Items $\mathrm{km}^{-2}-$ Year=37.11, $\left.11 \mathrm{df}, \mathrm{P}<0.001\right)$. Pairwise comparisons between years show that there were only significant differences between the years 2006 and 2007 and other years in both cases (Appendix 1).

\section{Categories and sources}

Fisheries was found to be the main source of marine litter, as is shown by the percentages of seabed litter presence grouped by categories and by their equivalent source (Table 2). Of the trawls with presence of litter, $61.9 \%$ showed litter included in the fisheriesrelated category. In most cases the litter was composed of small fragments of rope, but in some cases it was composed of entire fishing gears such as traps and nets (see Fig. 3).

Plastics and metal were the next most abundant categories, appearing in $18.6 \%$, and $16.5 \%$ of the trawls with presence of litter, respectively. These marine litter items included cans, bottles, bags and other pieces of plastic and metal. In addition, plastic and metal accounted for the vast majority of the material found on the seabed when the percentage of seabed litter com-

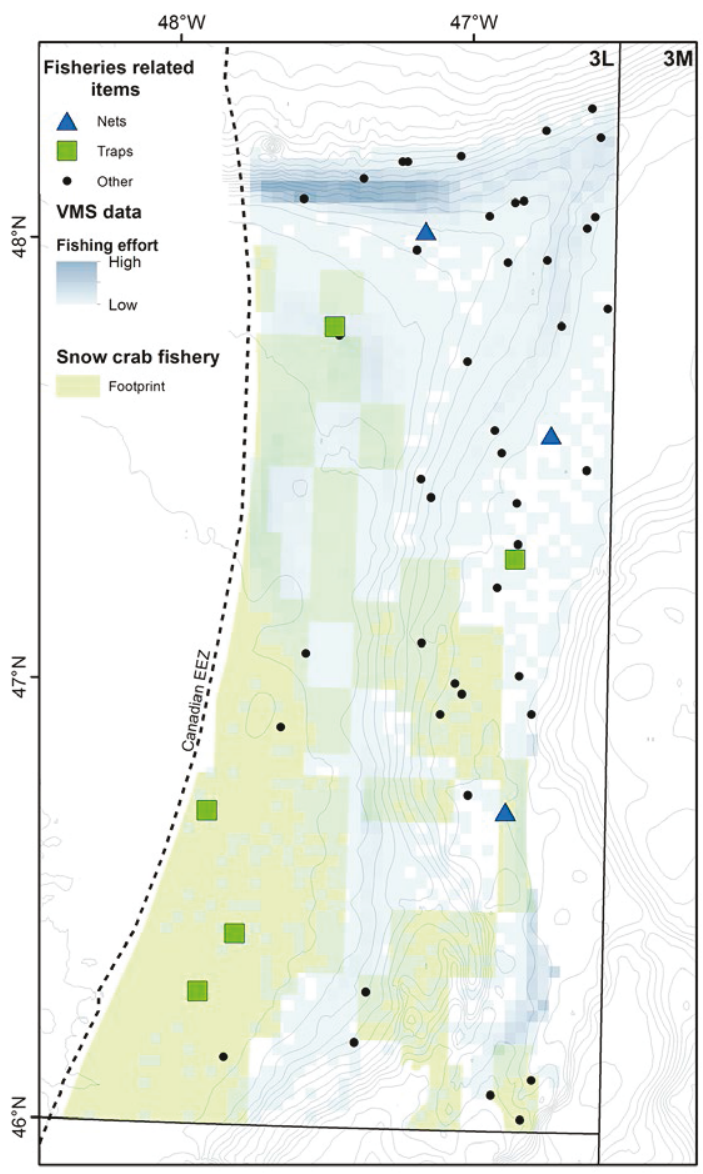

Fig. 3. - Distribution of fisheries-related seabed litter items found in the Flemish Pass area, showing in blue the fishing effort (all nonsedentary bottom fisheries based on 2008-2014 vessel monitoring system data) and in green the crab snow fishery (sedentary fishery) footprint (2007-2017). 
Table 2. - Percentage of occurrence of litter categories by trawls with litter presence (\%) and their equivalent source. The three columns on the right represent the percentage of litter presence $(\%)$, the mean values of marine litter densities estimated by $\mathrm{kg} \mathrm{km}^{-2}$ and number of items $\mathrm{km}^{-2}$ by valid trawls performed.

\begin{tabular}{cllcc}
\hline \multicolumn{1}{c}{ Categories } & Source & $\%$ & $\mathrm{Kg} \mathrm{km}^{-2}$ & $\mathrm{Item} \mathrm{km}^{-2}$ \\
\hline 61.9 & Fisheries related litter & Fisheries, including aquaculture & 5 & $9.9 \pm 5.2$ \\
18.6 & Plastics & & $0.8 \pm 0.1$ & 1.5 \\
16.5 & Metal & Galley waste from shipping, fisheries and offshore & 1.4 & $0.2 \pm 0.04$ \\
12.4 & Other anthropogenic litter & activities & $0.3 \pm 0.1$ & $0.3 \pm 0.1$ \\
2.1 & Glass & (non-operational waste) & $0.2 \pm 0.04$ & $<0.1$ \\
2.1 & Wood & & 0.2 & $<0.1$ \\
1.0 & Organic debris & $<0.1$ & $<0.1$ \\
\hline
\end{tabular}

posed of these two components that arose from fisheries was added, although most of this was plastic. Other anthropogenic litter appeared in $12.4 \%$ of the hauls, glass and wood in $2 \%$ and organic debris in only $1 \%$.
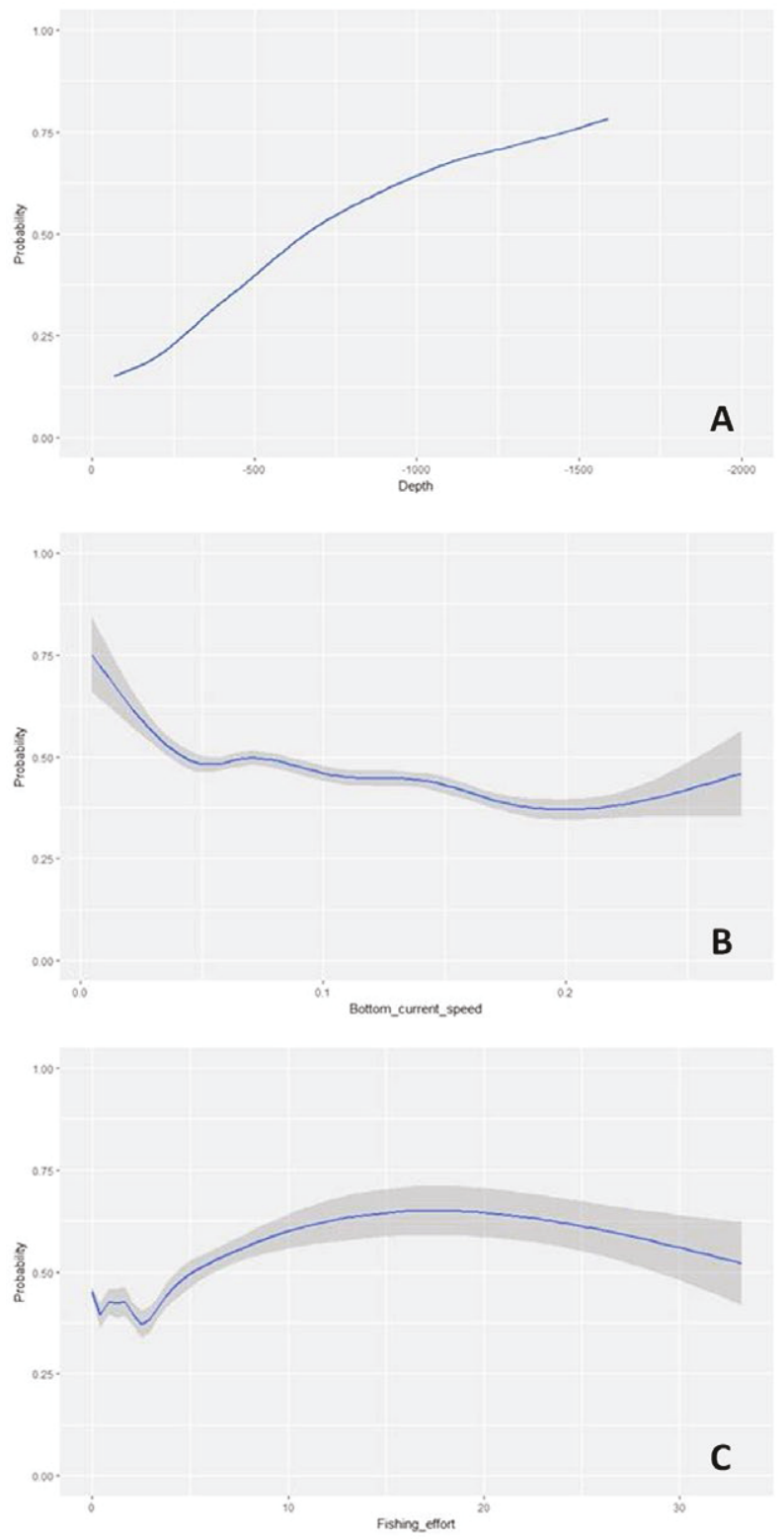

Fig. 4. - Partial generalized additive model plots for the selected continuous variables for seabed litter distribution. A, depth; B, bottom current speed; and $\mathrm{C}$, fishing effort. Each plot represents the response variable shape, independent of the other variables, in relation to the probability of the seabed litter occurrence. Confidence intervals $(95 \%)$ around the response curve are shaded in grey.
Identifying the source for the fishing gear category items (traps, nets, ropes, etc.) was straightforward (they correspond to the "Fisheries, including aquaculture" source) but for other items (cans, bottles, jars, etc.) it was intricate, so they were included in the broader source "Galley waste from shipping, fisheries and offshore activities (non-operational waste)", (For example, it is not possible to distinguish whether a can came from a fishing vessel, a cargo vessel or another offshore activity).

\section{Relation to depth, fishing effort and bottom current speed}

The generalized additive model, which explained $14.8 \%$ of the variance, shows that only depth had a significant effect on the litter distribution ( $\mathrm{p}$-value $<0.001$ ). Figure 4 shows the correlation between the three potential predictor variables tested on the predicted distribution of marine litter. Whereas fishing effort and bottom current speed showed no clear trend, the shape of the smoother of the depth highlights an increasing pattern with respect to marine litter occurrence. Higher depths occur on the Flemish Pass, the channel that separates the Flemish Cap offshore bank and the Grand Banks of Newfoundland, and down the northeastern flank of the Grand Banks. These areas show (Fig. 2) higher densities of marine litter.

\section{DISCUSSION}

\section{Characterization of the marine litter}

The percentage of presence of seabed litter in the survey trawls and the values of the density indicators were generally low across the Flemish Pass. This finding could be explained by the location of the study area in the high seas, far from the coast.

The present study was the first approximation of seabed litter distribution in the Flemish Pass area and one of the first focusing on the high seas. Pham et al. (2014) summarize results for various areas of European waters, which differed greatly. Thus, nowadays seem that it was difficult to compare results regarding seabed litter due to the different methodologies (nets or imaging technology) used in each study. Similarly, Lopez-Lopez et al. (2017) synthesize marine litter density results obtained in different studies in European Continental shelf areas, but using only bottom trawling as a sampling method; again, the difference in results was high (from 97 to 6000 items $\mathrm{km}^{-2}$ ) and in all cases higher than our own. In 

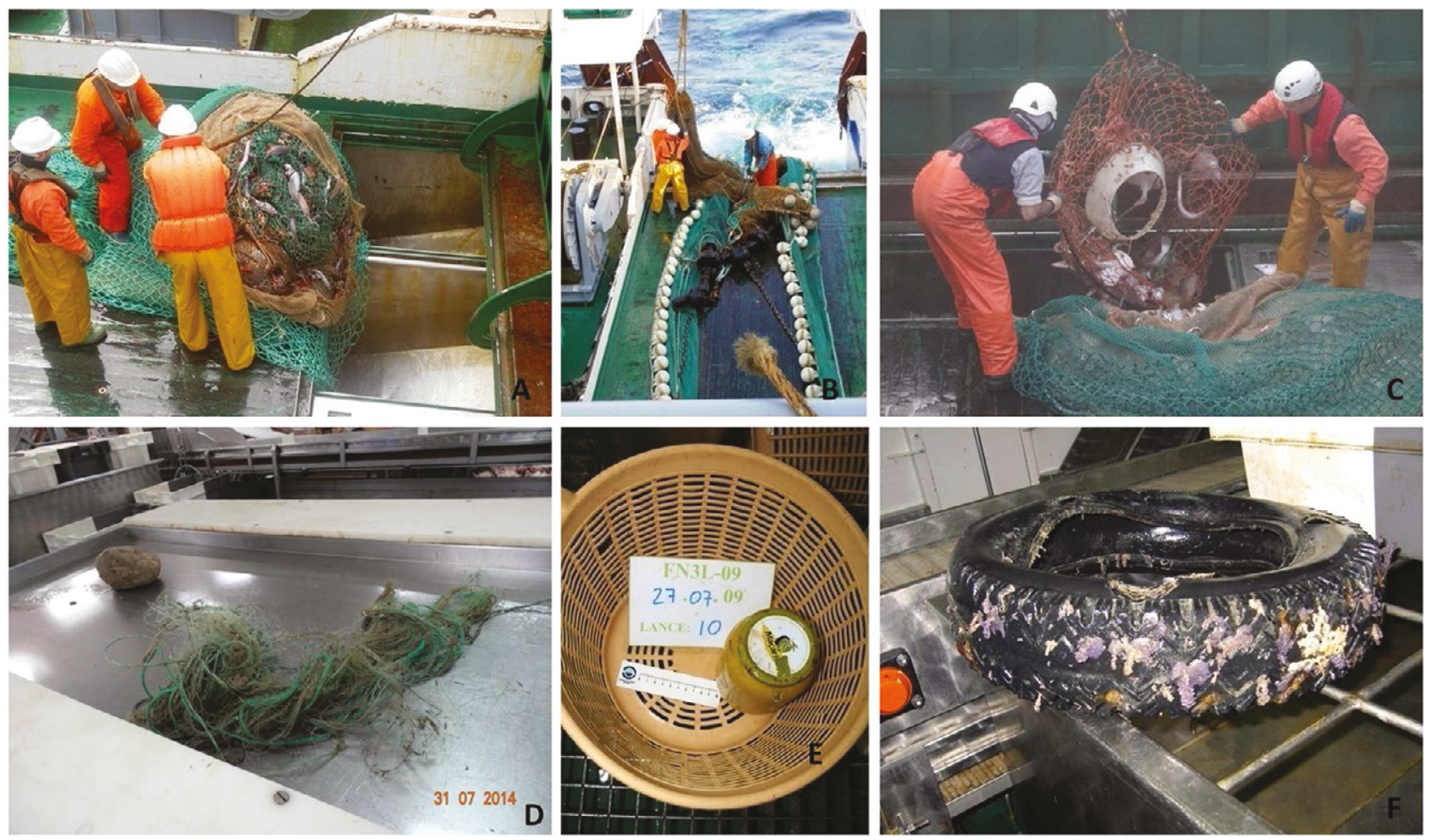

Fig. 5. - Seabed litter items found in the Flemish Pass. A-D, ALDFG items. A and B, being items found in two trawls hauls in 2007 with a weight of 400 and $250 \mathrm{~kg}$, respectively. E, a mustard pot and F, a tyre.

addition, Lee et al. (2006), in a study of seabed litter in an broad offshore area (more comparable with our study area) in the East China Sea that also used surveys trawls found a higher seabed litter density $\left(30.6 \mathrm{~kg} \mathrm{~km}^{-2}\right)$ than in the Flemish Pass area.

Bottom trawling is a common sampling method applied to study seabed marine litter (Galgani et al. 2010, Neves et al. 2015, Lopez-Lopez et al. 2017). The data used in the present study were obtained from bottom trawl groundfish surveys focusing on the assessment of demersal fish stocks. As in other studies in different areas, the sampling of seabed litter was a secondary objective of these surveys. There could therefore have been underestimations of seabed litter distribution due to mesh size and the opening of the bottom trawl gear (Spengler and Costa 2008): some type of items could not be retained by the net due to their size or could have been lost during the retrieving of the gear. Moreover, bottom trawling cannot be used on hard bottoms, and Melli et al. (2017) mentioned that seabed litter tends to accumulate close to rocks or in rocky habitats.

\section{Different indicators for describing marine litter}

Due to the large variety of seabed litter types collected by the gear (Fig. 5), the selection of the best indicator to describe their distribution and density was a difficult issue. As was noted by Pham et al. (2014), there are advantages and disadvantages of using seabed litter indicators based on items and weights in trawlbased studies. In addition to these two indicators, we also used the percentage of trawls with presence of litter, in order to resolve the disadvantage of an items- based indicator (some items can break into pieces and thus be overestimated).

Moreover, the use of percentage of trawls with presence of litter avoided comparing litter distribution based on large differences in weight (the $\mathrm{kg} \mathrm{km}^{-2}$ density indicator), as was observed in our study: heavy items such as traps (Fig. 5C) and nets (Fig. 5A, B) were not comparable with light items such as cans, pots (Fig. $5 \mathrm{E}$ ) and fragments of rope (Fig. 5D). The European Marine Strategy Framework Directive establishes only as obligatory the number of items for monitoring marine litter, while weight is only recommended (Galgani et al. 2013). However, in order to describe better the seabed litter distribution, we encourage the collection of data on number and weight and the use of other associated indicators such as the percentage of trawls with a presence of litter.

\section{Sources for marine litter}

The identification of the sources of litter is essential to implement management measures to reduce the presence of marine litter and mitigate its impact (Veiga et al. 2016). The Flemish Pass is far from the coast, so the influence of land sources is expected to be low. Moreover, the area hosts trawl and pot fisheries, shipping lanes and offshore oil and gas activities (ATLAS 2018). Taking this into account, seabed litter found in the present study could be considered as derived from sea-based activities included in two main sources (OSPAR 2007a): (i) fisheries and aquaculture and (ii) galley waste from shipping, fisheries and offshore activities (non-operational waste). 
Historically, high seas fisheries have been the most important human activity in the area, so it was not surprising that fisheries were identified as the main source of marine litter in the Flemish Pass. As other authors suggest (Moore and Allen 2000, Lee et al. 2006, Vieira et al. 2015), litter from fishing activity is usually prevalent in fishing grounds. In our study, some examples of entire fishing gears found in the trawls were two trawling nets weighing $400 \mathrm{~kg}$ and $250 \mathrm{~kg}$ (Fig 2C, $5 \mathrm{~A}, \mathrm{~B})$ and five traps where three of the five locations overlapped clearly with the snow crab fishery footprint (DFO 2018) (Fig. 3, 5C). Management measures should focus on encouraging fishermen to minimize ALDFG and also to land the marine litter that is captured. For instance, in the fishing for litter scheme, fishermen land marine litter trapped in their nets. This initiative is being applied increasingly in several countries due to the promotion of European directives, international strategies and conventions (OSPAR 2007b, Ronchi et al. 2018). Among other measures, fishermen are provided with large, hardwearing bags to accumulate the marine litter, and facilities are offered in ports for the fishermen to deposit the litter at no cost.

In our study, it was not possible to identify the source of certain items such as cans and bottles because in the Flemish Pass, in addition to fishing and shipping, other human activities occur (ATLAS 2018) that could potentially cause that waste (UNEP 2005). It is worth noting that during recent years there has been an increase in offshore hydrocarbon exploration activities in the area (CEA 2019). Therefore, in terms of source, these non-specific items were classified as "galley waste from shipping, fisheries and offshore activities".

\section{Potential drivers of seabed litter distribution}

Currents, geomorphologic features and human activities are variables that influence the spatial distribution of seabed litter (Pham et al. 2014, Sánchez et al. 2013, Lopez-Lopez et al. 2017). We therefore studied the influence of bottom currents, depth and fishing effort with the aim of better understanding the distribution patterns of seabed litter in the Flemish Pass. A significant effect with depth was found: the presence of litter increased linearly with depth (Fig. 4A).

These results agree with the spatial distribution observed in the present study (Fig. 2): the highest occurrences and densities of seabed litter were found in the northern and northeastern part of the study area, where the deepest bottoms are located. A similar distribution pattern influenced by depth has been reported in other studies for the US western coast (Moore and Allen 2000, Keller et al. 2010). Moreover, Keller et al. (2010) state that debris from sea-based sources follows this pattern rather than debris from land-based sources. This is the case of the Flemish Pass, located far from land, where sea-based sources of litter are expected to be dominant.

A non-significant relationship with bottom currents was found. However, this result should be used with caution because the spatial resolution of the data used in the present study may not characterize these vari- ables well in the area. The bottom current information was based on an ocean basin model that may not incorporate the specific geomorphologic characteristics of the study area and therefore the bottom current speed in the Flemish Pass.

Regarding the influence of fishing effort, though most of the litter items were related to fisheries, no significant relationship was found between fishing effort and seabed litter distribution. This could be due to the litter settlement process influenced by other variables such as currents. In the case of heavy items (e.g. entire fishing gears), less influenced by the settlement process, the explanation could be the fact that fishermen relocate these items to marine dumps or just clean the fishing ground areas where they have trawled, as has been suggested by other studies (Neves et al. 2015, Lopez-Lopez et al. 2017). These reasons could also explain the higher values observed at the start of the survey series (the years 2006 and 2007) than in later years (Table 1).

The case of the aforementioned traps (overlapped with the snow crab fishery footprint) was different, as is shown in Figure 3. The traps remained in the fishery area and were not relocated. The reason could be that this area was not trawled. It is important to note also that the snow crab fishery was not included in the fishing effort calculation used, though the effect of the fishing effort should not have varied because of the small scale of this fishery in the area. Sánchez et al. (2013) also found no relationship between fishing effort and marine debris in northern Mediterranean fishing grounds subjected to different effort intensities, but in this case few items related to fisheries were found.

\section{CONCLUSIONS AND FUTURE WORK}

This study presents baseline information on seabed litter in this area, where no studies have been carried out before. It thus contributes valuable new data on deep-sea litter on the high seas. The study illustrates the opportunities, advantages and disadvantages of using groundfish bottom trawl surveys to investigate densities, spatial distribution, composition and sources of seabed marine litter.

Standardized protocols for marine litter data collection in NAFO groundfish surveys were done to apply to the other two surveys taking place every summer in Flemish Cap and in the Tail of the Grand Bank (NAFO Divs 3M-3NO, outside the Canadian exclusive economic zone). This could be an important contribution to marine litter knowledge in the high seas and allow comparisons with the data in the Flemish Pass. There is currently global concern about the importance of monitoring marine litter in a standardized way. Some efforts from the scientific community are asking for a global monitoring strategy such as the Integrated Marine Debris Observing System (Maximenko et al. 2019).

We found low values for seabed litter in the area, which could be explained by their great distance from the coast where sea-based and mostly fisheries was the source. This finding was not unexpected, because fishing activity had historically been the most impor- 
tant human activity in the area. The fact that fisheries were identified as the main source of the marine litter presence in this area facilitates the implementation of management measures to mitigate and monitor this environmental problem. The management procedures should focus on encourage fishermen to land the marine litter found during their fishing activities, to mitigate ALDFG during fishing activities and to monitor the litter discarded at sea.

\section{ACKNOWLEDGEMENTS}

The authors are very grateful to all the participants in the EU NAFO Groundfish surveys carried out on the research vessel Vizconde de Eza (SGP), which made this work possible.

EU NAFO Groundfish surveys were co-funded by the European Union through the European Maritime and Fisheries Fund (EMFF) within the national programme of collection, management and use of data in the fisheries sector and support for scientific advice regarding the Common Fisheries Policy. A. GarcíaAlegre, M. Sacau and P. Durán Muñoz were supported by the Atlas project, E. Román by the BIOPESLE project and J. Gago and G. González-Nuevo by the CLEANATLANTIC (INTERREG-Atlantic Area) project. The ATLAS project received funding from the European Union's Horizon 2020 research and innovation programme under grant agreement No 678760. This output reflects only the author's view and the European Union cannot be held responsible for any use that may be made of the information contained therein.

\section{REFERENCES}

ATLAS. 2018. ATLAS Deliverable D6.1: Sectoral activities, institutional landscape, existing management plans and MSP goals. ATLAS (Grant agreement no. 678760).

Behrens E., Våge K., Harden B., et al. 2017. Composition and variability of the Denmark Strait Overflow Water in a highresolution numerical model hindcast simulation. J. Geophys. Res. Ocean. 122: 2830-2846. https://doi.org/10.1002/2016JC012158

Bergmann M., Gutow L., Klages M. (eds). 2015. Marine anthropogenic litter. Springer. $447 \mathrm{pp}$. https://doi.org/10.1007/978-3-319-16510-3

Bilkovic D.M., Havens K., Stanhope D., et al. 2014. Derelict fishing gear in Chesapeake Bay, Virginia: Spatial patterns and implications for marine fauna. Mar. Poll. Bull. 80: 114-123. https://doi.org/10.1016/j.marpolbul.2014.01.034

Bishop C.A. 1994. Revision and additions to stratification schemes used during research vessel surveys in NAFO Subareas 2 and 3. NAFO SCR Doc., No 43, Serial No N2413, 23 pp.

Breusing C., Biastoch A., Drews A., et al. 2016. Biophysical and Population Genetic Models Predict the Presence of "Phantom" Stepping Stones Connecting Mid-Atlantic Ridge Vent Ecosystems. Curr. Biol. 26: 2257-2267. https://doi.org/10.1016/j.cub.2016.06.062

Canadian Environmental Assessment Agency (CEA). 2019. Flemish Pass Exploration Drilling Project and Eastern Newfoundland Offshore Exploration Drilling Project - Public Comments Invited. Accessed 12.03.2019. Available at: https://ceaa-acee.gc.ca/050/evaluations/document/ 126792? culture=en-CA

Colbourne E.B., Foote K.D. 2000. Variability of the stratification and circulation on the Flemish Cap during the decades of the 1950s-1990s. J. Northwest Atl. Fish. Sci. 26: 103-122. https://doi.org/10.2960/J.v26.a5

Cózar A., Echevarría F., González-Gordillo J.I., et al. 2014. Plastic debris in the open ocean. Proc. Natl. Acad. Sci. U.S.A. 111:
10239-10244

https://doi.org/10.1073/pnas.1314705111

DFO. 2018. Assessment of Newfoundland and Labrador (Divisions 2HJ3KLNOP4R) Snow Crab. DFO Canadian Science Advisory Secretariat Science Advisory Report 2018/024.

Doubleday W.G. 1981. Manual of Groundfish Surveys in the Northwest Atlantic. NAFO Sci. Coun. Studies 2: 7-55.

Durán Muñoz P., Sayago-Gil M., Murillo F.J., et al. 2012. Actions taken by fishing Nations towards identification and protection of vulnerable marine ecosystems in the high seas: The Spanish case (Atlantic Ocean). Mar. Policy 36: 536-543. https://doi.org/10.1016/j.marpol.2011.09.005

Edyvane K.S., Dalgetty A., Hone P.W. et al. 2004. Long-term marine litter monitoring in the remote Great Australian Bight, South Australia. Mar. Pollut. Bull. 48: 1060-1075. https://doi.org/10.1016/j.marpolbul.2003.12.012

Gago J., Lahuerta F., Antelo P. 2014. Characteristics (abundance, type and origin) of beach litter on the Galician coast (NW Spain) from 2001 to 2010. Sci. Mar. 78: 125-134. https://doi.org/10.3989/scimar.03883.31B

Galgani F., Fleet D., Van Franeker J., et al. 2010. Marine Strategy Framework Directive Task Group 10 Report Marine litter. European Commission, EUR 24340 EN - Joint Research Centre, Luxembourg, 48 pp.

Galgani F., Hanke G., Werner S., et al. 2013. Marine litter within the European Marine Strategy Framework Directive. ICES J. Mar. Sci. 70: 1055-1064 https://doi.org/10.1093/icesjms/fst122

Galgani F., Hanke G., Maes T. 2015. Global distribution, composition and abundance of marine litter, In: Bergmann, M., Gutow, L., et al. (eds), Marine Anthropogenic Litter. Springer, pp. 29-56. https://doi.org/10.1007/978-3-319-16510-3 2

García-Rivera S., Lizaso J.L.S., Millán J.M.B. 2018. Spatial and temporal trends of marine litter in the Spanish Mediterranean seafloor. Mar. Pollut. Bull. 137: 252-261. https://doi.org/10.1016/j.marpolbul.2018.09.051

Gilman E., Chopin F., Suuronen P., et al. 2016. Abandoned, lost or otherwise discarded gillnets and trammel nets: methods to estimate ghost fishing mortality, and the status of regional monitoring and management. FAO Fish. Aquac. Tech. Pap. No. 600. Rome.

Hastie T., Tibshirani R., Friedman J.H. 2001. The Elements of Statistical Learning: Data Mining, Inference, and Prediction. Springer, New York, NJ. https://doi.org/10.1007/978-0-387-21606-5

Hijmans R.J., van Etten J., Cheng J., et al. 2016. Package 'raster'. $R$ package.

Hong S., Lee J., Kang D., et al. 2014. Quantities, composition, and sources of beach debris in Korea from the results of nationwide monitoring. Mar. Pollut. Bull. 84: 27-34. https://doi.org/10.1016/j.marpolbul.2014.05.051

Jang Y.C., Lee J., Hong S., et al. 2014. Sources of plasticmarine debris on beaches of Korea: More from the ocean than the land. Ocean Sci. J. 49: 151-162. https://doi.org/10.1007/s12601-014-0015-8

Keller A.A., Fruh E.L., Johnson M.M., et al. 2010. Distribution and abundance of anthropogenic marine debris along the shelf and slope of the US West Coast. Mar. Pollut. Bull. 60: 692-700. https://doi.org/10.1016/j.marpolbul.2009.12.006

Lee D.I., Cho H.S., Jeong S.B. 2006. Distribution characteristics of marine litter on the sea bed of the East China Sea and the South Sea of Korea. Estuar. Coast. Shelf Sci. 70: 187-194.

Lopez-Lopez L., González-Irusta J.M., Punzón A., et al. 2017. Benthic litter distribution on circalittoral and deep sea bottoms of the southern Bay of Biscay: Analysis of potential drivers. Cont. Shelf Res. 144: 112-119. https://doi.org/10.1016/j.csr.2017.07.003

Lusher A.L., Hollman P.C.H., Mendoza-Hill J.J. 2017. Microplastics in fisheries and aquaculture: status of knowledge on their occurrence and implications for aquatic organisms and food safety. FAO Fish. Aquac. Tech. Pap. No. 615. Rome, Italy.

McCallum B. R., Walsh S.J. 1994. Survey Trawl Reference Manual: Campelen 1800. Dep. Fish. Oceans, Newfoundland, Canada.

Maes T., Barry J., Leslie H.A., et al. 2018. Below the surface: Twenty-five years of seafloor litter monitoring in coastal seas of North West Europe (1992-2017). Sci. Total Environ. 630: 790-798.

https://doi.org/10.1016/j.scitotenv.2018.02.245

Maximenko N., Corradi P., Law K.L., et al. 2019. Toward the In- 
tegrated Marine Debris Observing System. Front. Mar. Sci. 6: 447.

https://doi.org/10.3389/fmars.2019.00447

Melli V., Angiolillo M., Ronchi F., et al. 2017. The first assessment of marine debris in a Site of Community Importance in the north-western Adriatic Sea (Mediterranean Sea). Mar. Pollut. Bull. 114: 821-830. https://doi.org/10.1016/j.marpolbul.2016.11.012

Moore S.L., Allen J. 2000. Distribution of anthropogenic and natural debris on the mainland shelf of the Southern California Bight. Mar. Pollut. Bull. 40: 83-88.

Moriarty M., Pedreschi D., Stokes D., et al. 2016. Spatial and temporal analysis of litter in the Celtic Sea from groundfish survey data: lessons for monitoring. Mar. Pollut. Bull. 103: 195-205. https://doi.org/10.1016/j.marpolbul.2015.12.019

Murillo F.J., Durán Muñoz P., Altuna A., et al. 2011. Distribution of deep-water corals of the Flemish Cap, Flemish Pass, and the Grand Banks of Newfoundland (Northwest Atlantic Ocean): interaction with fishing activities. ICES J. Mar. Sci. 68: 319-332. https://doi.org/10.1093/icesjms/fsq071

Murillo F.J., Muñoz P.D., Cristobo J., et al. 2012. Deep-sea sponge grounds of the Flemish Cap, Flemish Pass and the Grand Banks of Newfoundland (Northwest Atlantic Ocean): distribution and species composition. Mar. Biol. Res. 8: 842-854. https://doi.org/10.1080/17451000.2012.682583

NAFO. 2015. Report of the 8th Meeting of the NAFO Scientific Council Working Group on Ecosystem Science and Assessment (WGESA). NAFO SCS Doc. 15/19, Serial No. N6549, 176 pp.

Neves D., Sobral P., Pereira T. 2015. Marine litter in bottom trawls off the Portuguese coast. Mar. Pollut. Bull. 99: 301-304. https://doi.org/10.1016/j.marpolbul.2015.07.044

OSPAR. 2007a. Monitoring of Marine litter in the OSPAR Region. Publication No. 306/2007. London, United Kingdom, 74 pp.

OSPAR. 2007b. Guidelines on how to develop a fishing for litter project. Publication No. 325/ 10. 15 pp.

Pham C.K., Ramirez-Llodra E., et al. 2014. Marine litter distribution and density in European seas, from the shelves to deep basins. PLoS One 9: e95839. https://doi.org/10.1371/journal.pone.0095839

R Core Team. 2017. R: A Language and Environment for Statistical Computing.

https://www.R-project.org/

Román E., González-Iglesias C., González-Troncoso D. 2018. Re- sults for the Spanish Survey in the NAFO Regulatory Area of Division 3L for the period 2003-2017. NAFO SCR Doc. No. 18, Serial No 6803 .

Ronchi F., Galgani F., Binda F., et al. 2018. Fishing for Litter in the Adriatic-Ionian macroregion (Mediterranean Sea): Strengths, weaknesses, opportunities and threats. Mar. Policy 100: 226-237.

https://doi.org/10.1016/j.marpol.2018.11.041

Sánchez P., Masó M., Sáez Liante R., et al. 2013. Baseline study of the distribution of marine debris on soft-bottom habitats associated with trawling grounds in the northern Mediterranean. Sci. Mar. 77: 247-255.

https://doi.org/10.3989/scimar03702.10A

Sbrocco E.J., Barber P. H. 2013. MARSPEC: ocean climate layers for marine spatial ecology: Ecological Archives E094-086. Ecology 94: 979-979. https://doi.org/10.1890/12-1358.1

Spengler A., Costa M.F. 2008. Methods applied in studies of benthic marine debris. Mar. Pollut. Bull. 56: 226-230. https://doi.org/10.1016/j.marpolbul.2007.09.040

UNEP. 2005. Marine Litter, an analytical overview. United Nations Environment Programme. Nairobi, Kenya. 48 pp.

UNEP. 2016. Marine plastic debris and microplastics - Global lessons and research to inspire action and guide policy change. United Nations Environment Programme, Nairobi, Kenya.

Veiga J.M., Fleet D., Kinsey S., et al. 2016. Identifying Sources of Marine Litter. MSFD GES TG Marine Litter Thematic Report; JRC Technical Report; EUR 28309. https://doi.org/10.2788/018068

Vieira R.P., Raposo I.P., Sobral P., et al. 2015. Lost fishing gear and litter at Gorringe Bank (NE Atlantic). J. Sea Res. 100: 91-98. https://doi.org/10.1016/j.seares.2014.10.005

Wood S.N. 2003. Thin plate regression splines. J. R. Stat. Soc. Ser. B (Stat. Method.) 65: 95-114 https://doi.org/10.1111/1467-9868.00374

Wood S.N., Augustin N.H. 2002. GAMs with integrated model selection using penalized regression splines and applications to environmental modelling. Ecol. Modelling 157: 157-177. https://doi.org/10.1016/S0304-3800(02)00193-X

Zuur A.F., Ieno E.N., Elphick C.S. 2010. A protocol for data exploration to avoid common statistical problems. Methods Ecol. Evol. 1: 3-14

https://doi.org/10.1111/j.2041-210X.2009.00001.x

\section{APPENDIX}

Appendix 1. - Pairwise comparisons using a Wilcoxon rank sum test between years of items km-2 (A) and kg km${ }^{-2}$ (B).

\begin{tabular}{cccccccccccc}
\hline \multicolumn{2}{c}{ A (items km ${ }^{-2}$ ) } & & & & & & & & & & \\
& 2006 & 2007 & 2008 & 2009 & 2010 & 2011 & 2012 & 2013 & 2014 & 2015 & 2016 \\
\hline 2007 & 0.856 & - & - & - & - & - & - & - & - & - & - \\
2008 & 0.079 & 0.157 & - & - & - & - & - & - & - & - & - \\
2009 & 0.044 & 0.101 & 0.856 & - & - & - & - & - & - & - & - \\
2010 & 0.027 & 0.034 & 0.627 & 0.763 & - & - & - & - & - & - & - \\
2011 & 0.027 & 0.032 & 0.529 & 0.627 & 0.856 & - & - & - & - & - & - \\
2012 & 0.124 & 0.229 & 0.856 & 0.775 & 0.529 & 0.445 & - & - & - & - & - \\
2013 & 0.027 & 0.034 & 0.627 & 0.763 & 0.994 & 0.856 & 0.529 & - & - & - & - \\
2014 & 0.032 & 0.047 & 0.763 & 0.856 & 0.856 & 0.775 & 0.627 & 0.856 & - & - & - \\
2015 & 0.032 & 0.044 & 0.763 & 0.856 & 0.856 & 0.775 & 0.627 & 0.856 & 0.994 & - & - \\
2016 & 0.334 & 0.529 & 0.548 & 0.449 & 0.174 & 0.135 & 0.680 & 0.164 & 0.258 & 0.238 & - \\
2017 & 0.102 & 0.185 & 0.878 & 0.804 & 0.529 & 0.449 & 0.968 & 0.529 & 0.627 & 0.627 & 0.627 \\
\hline $\mathrm{B}\left(\mathrm{kg} \mathrm{km} \mathrm{km}^{-2}\right)$ & & & & & & & & & & & \\
& 2006 & 2007 & 2008 & 2009 & 2010 & 2011 & 2012 & 2013 & 2014 & 2015 & 2016 \\
\hline 2007 & 0.924 & - & - & - & - & - & - & - & - & - & - \\
2008 & 0.088 & 0.138 & - & - & - & - & - & - & - & - & - \\
2009 & 0.057 & 0.088 & 0.875 & - & - & - & - & - & - & - & - \\
2010 & 0.031 & 0.037 & 0.629 & 0.765 & - & - & - & - & - & - & - \\
2011 & 0.031 & 0.037 & 0.535 & 0.670 & 0.875 & - & - & - & - & - & - \\
2012 & 0.138 & 0.198 & 0.875 & 0.778 & 0.513 & 0.439 & - & - & - & - & - \\
2013 & 0.031 & 0.037 & 0.629 & 0.765 & 0.995 & 0.875 & 0.513 & - & - & - & - \\
2014 & 0.037 & 0.057 & 0.795 & 0.875 & 0.857 & 0.777 & 0.670 & 0.857 & - & - & - \\
2015 & 0.037 & 0.057 & 0.778 & 0.875 & 0.857 & 0.777 & 0.670 & 0.857 & 0.995 & - & - \\
2016 & 0.522 & 0.629 & 0.513 & 0.356 & 0.138 & 0.126 & 0.629 & 0.139 & 0.255 & 0.255 & - \\
2017 & 0.138 & 0.198 & 0.875 & 0.777 & 0.513 & 0.439 & 0.995 & 0.513 & 0.674 & 0.670 & 0.629 \\
\hline
\end{tabular}

